\title{
Lung dust content in idiopathic pulmonary fibrosis: a study with scanning electron microscopy and energy dispersive $x$ ray analysis
}

E Monsó, J M Tura, J Pujadas, F Morell, J Ruiz, J Morera

\begin{abstract}
Examination with an optical microscope and polarised light is not sensitive enough to detect low diameter asbestos fibres. This limitation implies that some cases of asbestosis can be erroneously diagnosed as idiopathic pulmonary fibrosis (IPF) if asbestos bodies are not found in the standard examination of abnormal tissue. To determine whether IPF is overdiagnosed, a study was carried out with scanning electron microscopy (SEM) and energy dispersive $x$ ray analysis (EDXA) on 25 samples previously diagnosed as IPF at the standard examination. Scanning electron microscopy will show the presence of low diameter fibres in the lung without tissue destruction, and these fibres can be identified using EDXA. The quantitative and qualitative results for lung tissue from patients diagnosed as having IPF were compared with the results of the examination of 25 samples of normal lung. Most of the samples from patients diagnosed as having IPF showed only occasional inorganic particles $(<10$ particles/SEM field at $160 \times)$, results equivalent to the results obtained in normal lung. Two cases of IPF, however, showed innumerable asbestos fibres ( $>100$ fibres/SEM field). One of these two patients had an antecedent of brief exposure to asbestos. No environmental antecedent was found in the second patient. Asbestosis was the final diagnosis for these two patients. The examination of inorganic particles in normal lungs showed mainly non-fibrous silicates $(61 \cdot 4 \%)$ and particles of heavy elements (34.9\%). Only one asbestos fibre was found $(0.9 \%)$. It is concluded that standard pathological techniques overdiagnose IPF in a few cases in which asbestos bodies are not found with the optical microscope.
\end{abstract}

Serveis de Pneumologia, Hospital Germans Trias i Pujol (Badalona) i Hospital Vall d'Hebron (Barcelona). ITQT Consell Superior d'Investigacions Cientifiques (Barcelona), Catalonia, Spain E Monsó, J M Tura, J Pujadas, F Morell, J Ruiz, J Morera
A lung sample showing pulmonary fibrosis and inorganic particles allows the diagnosis of pneumoconiosis. Absence of inorganic particles in a fibrotic lung sample of a patient with diffuse interstitial lung disease, if no other cause is determined, usually gives a diagnosis of idiopathic pulmonary fibrosis (IPF). It is well known, however, that examination with an optical microscope and polarised light is not sensitive enough to detect low diameter inorganic particles, especially asbestos fibres. For lung samples from patients previously diagnosed by optical microscopy as having IPF, an examination using more sensitive techniques could find that some of the samples contain enough asbestos fibres to diagnose asbestosis.

Advances in mineralogical analysis have enabled its application in pneumology during the last two decades. ${ }^{1-3}$ Among the techniques applicable to organic matter, scanning electron microscopy (SEM) with energy dispersive $x$ ray analysis (EDXA) is especially useful. ${ }^{45}$ Inorganic particles in the lung are easily identified if secondary and backscattered imaging are used (spot $0.125 \mu \mathrm{m}$; maximum resolution power $150 \AA$ ). The atomic composition of every inorganic particle visualised can be identified using EDXA. If the area studied in all the samples is predetermined, a quantitative and qualitative examination can be done.

We studied 25 samples with a previous pathological diagnosis of IPF and 25 samples of normal lung, and determined the number of inorganic particles seen in the area visualised with SEM at $160 \times\left(278300 \mu \mathrm{m}^{2}\right)$, identifying their atomic composition with EDXA.

\section{Material and methods}

Twenty five histological samples of lung tissue from patients (mean age (SD) 58.3 (13.7); 14 men, 12 women) with a previous pathological diagnosis of IPF were studied. All samples were obtained by surgical biopsy, mainly from the lingula. Twenty two had a pathological diagnosis of usual interstitial pneumonia (UIP), two had UIP with a desquamative component, and one patient had giant cell interstitial pneumonia. Exposure history indicated that nine patients might have inhaled inorganic particles (table 
Table 1 Inhalatory antecedents in patients with idiopathic pulmonary fibrosis

\begin{tabular}{llll}
\hline Case No. & Sex & Age $(y)$ & Antecedent \\
\hline 1 & M & 39 & No antecedent \\
2 & W & 53 & No antecedent \\
3 & M & 71 & Quarry 20 years \\
4 & M & 55 & Cement < one year \\
5 & W & 54 & No antecedent \\
6 & W & 70 & No antecedent \\
7 & M & 58 & No antecedent \\
8 & W & 67 & Husband asbestos worker \\
9 & W & 78 & No antecedent \\
10 & M & 49 & Chemical industry > five years \\
11 & W & 50 & Rubber factory $>$ five years \\
12 & W & 23 & No antecedent \\
13 & M & 75 & No antecedent \\
14 & W & 52 & No antecedent \\
15 & M & 66 & No antecedent \\
16 & M & 44 & No antecedent \\
17 & M & 65 & No antecedent \\
18 & M & 72 & No antecedent \\
19 & M & 54 & Quarry > five years \\
20 & W & 31 & Chemicals < one year \\
21 & M & 70 & Asbestos three years \\
22 & W & 71 & No antecedent \\
23 & M & 72 & No antecedent \\
24 & W & 63 & No antecedent \\
25 & M & 56 & Asbestos 20 years \\
\hline
\end{tabular}

*Only antecedents that could imply inhalation of inorganic particles, even in small amounts were considered.

$M=M a n ; W=$ woman.

1). Pulmonary biopsy was indicated in these patients due to a brief exposition period or because diagnoses other than pneumoconiosis were considered, which could not be confirmed without an examination of pulmonary tissue. In these patients absence of inorganic particles in the examination by optical microscopy and polarised light precluded a diagnosis of pneumoconiosis.

Twenty five samples of normal lung were also examined from patients (mean age (SD) 62.8 (14.7); 12 men, 13 women) who had died, mainly of cardiovascular causes. Patients with a history of inhalation of inorganic particles were excluded by personal history and phone call to relatives. The samples were all obtained from peripheral areas of the lung.

Samples from cases of IPF were set in paraffin and samples of normal lung were kept in formalin. Thick sections were obtained from all samples; $20 \mu \mathrm{m}$ from those in paraffin and 1-2 $\mathrm{mm}$ from those in formalin. Paraffin samples were deparaffined in two baths of xylol. All samples were dried by the critical temperature method (Polaron E300) after substitution of the tissue water with acetone by immersion in baths of increasing concentration. For the SEM examination and mineralogical analysis the samples were placed on pure carbon stubs. We ruled out contamination of the stubs and paraffin with silica or silicates.

The SEM examination (Phillips SEM 500) was carried out first at low magnification $(160 \times)$ looking for a representative area of the pulmonary parenchyma and avoiding the peribronchial, perivascular, and subpleural areas. The area selected (magnification $160 \times\left(278300 \mu \mathrm{m}^{2}\right)$ was examined for inorganic particles increasing the magnification to $5000 \times$ to identify low diameter fibres. The visualised inorganic particles were quantified and the atomic composition of each was determined using EDXA (working conditions: $25 \mathrm{kV}$; spot $0.125 \mu \mathrm{m}$; detector stub distance $32.5 \mathrm{~mm}$; $x$ ray angle $20^{\circ}$ ), a spectrometric technique that detects all elements with an atomic number above $10 .^{67}$

The morphology and atomic composition of the particles visualised with the SEM and analysed with EDXA allows us to classify the inorganic particles as silica (detection of a peak of $\mathrm{Si}$ ), non-fibrous silicates ( $\mathrm{Si}$ with $\mathrm{Mg}, \mathrm{K}, \mathrm{Al}, \mathrm{Ca}$, or $\mathrm{Fe}$ ), asbestos (length: width ratio $>3 \leftarrow$ fibrous silicate with $\mathrm{Mg}$ or amphibole atomic composition), ${ }^{89}$ and particles of heavy elements $(\mathrm{Fe}, \mathrm{Pb}, \mathrm{Ti}, \mathrm{Ag}, \mathrm{Sn}$, or $\mathrm{Ba})$. The particles of elements with a possible organic origin (Ca) were not considered.

Table 2 Inorganic particles: idiopathic pulmonary fibrosis

\begin{tabular}{|c|c|c|}
\hline Patient & No of particles & Type \\
\hline 1 & 0 & - \\
\hline 2 & 1 & Silicate (1) \\
\hline 3 & 0 & - \\
\hline 4 & 0 & - \\
\hline 5 & 6 & Silicate (6) \\
\hline 6 & 7 & $\begin{array}{l}\text { Silicate (5) } \\
\text { Silica (1) } \\
\text { Fe (1) }\end{array}$ \\
\hline 7 & 7 & $\begin{array}{l}\text { Silicate (5) } \\
\text { Silica (1) } \\
\text { Al (1) }\end{array}$ \\
\hline 8 & 5 & $\begin{array}{l}\text { Silicate (3) } \\
\text { Silica (1) } \\
\text { ZnCu (1) }\end{array}$ \\
\hline 9 & 6 & $\begin{array}{l}\text { Silicate (2) } \\
\text { Silica (2) } \\
\text { Fe (1) } \\
\text { Al (1) }\end{array}$ \\
\hline 10 & 4 & $\begin{array}{l}\text { Silicate (2) } \\
\mathrm{ZnCu}(2)\end{array}$ \\
\hline 11 & 0 & - \\
\hline 12 & 5 & Silicate (5) \\
\hline 13 & 0 & - \\
\hline 14 & 6 & $\begin{array}{l}\text { Silicate (3) } \\
\text { Ba (1) } \\
\text { Co (2) }\end{array}$ \\
\hline 15 & 3 & $\begin{array}{l}\text { Silicate (1) } \\
\text { Silica (2) }\end{array}$ \\
\hline 16 & 0 & - \\
\hline 17 & 1 & Silicate (1) \\
\hline 18 & 1 & Silicate (1) \\
\hline 19 & 2 & $\begin{array}{l}\text { Silicate (1) } \\
\text { Fe (1) }\end{array}$ \\
\hline 20 & 10 & $\begin{array}{l}\text { Silicate (4) } \\
\mathrm{Cu}(6)\end{array}$ \\
\hline 21 & Innumerable & $\begin{array}{l}\text { Fibrous silicate } \\
\text { Fe (1) }\end{array}$ \\
\hline 22 & Innumerable & Fibrous silicate \\
\hline 23 & 5 & Silicate (5) \\
\hline 24 & - & - \\
\hline 25 & 0 & 一 \\
\hline
\end{tabular}




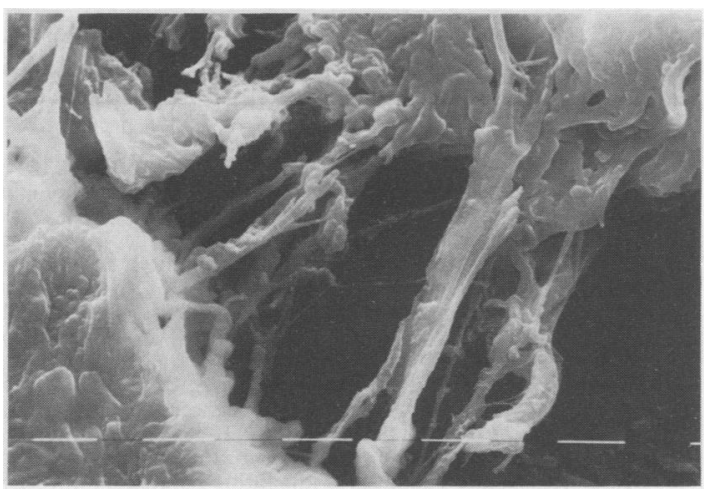

Figure 1 Asbestos fibres in a sample with a previous diagnosis of idiopathic pulmonary fibrosis (scanning electron microscopy $(250 \times)$.

\section{Results}

One sample of normal lung tissue and one sample of tissue from a patient with IPF were discarded from mineralogical analysis due to poor quality of the SEM imaging that impeded recognition of the inorganic particles. These samples were not considered in the results.

Most of the samples from patients diagnosed as having IPF contained only occasional inorganic particles ( $<10$ particles in the area studied), but two $(8.3 \%)$ showed innumerable asbestos fibres $(>100$ asbestos fibres in the area). One of these patients had an antecedent of a brief occupational exposure to asbestos. No relevant antecedent was found in the second patient (table 2; figures 1,2).

The twenty four samples of normal lung analysed

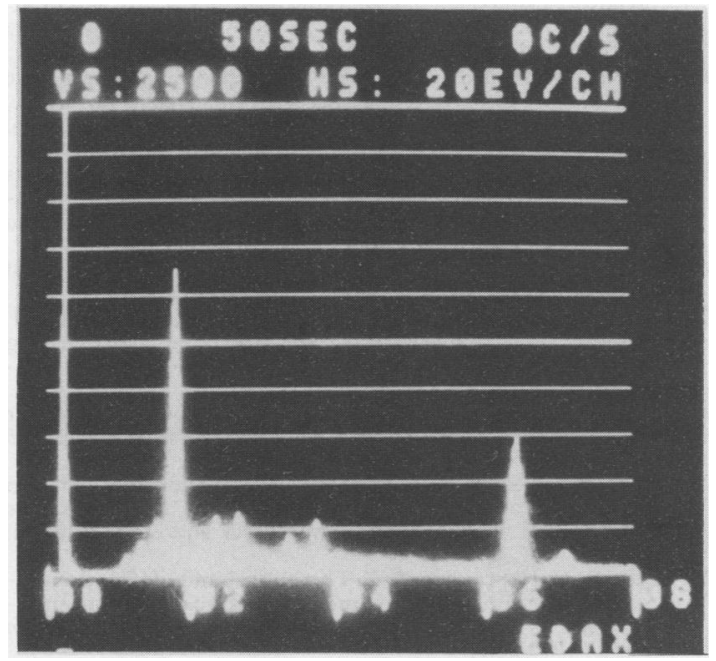

Figure 2 Energy dispersive $\mathrm{x}$ ray analysis of an asbestos fibre. showed only occasional inorganic particles in $18 / 24$ cases ( $<10$ particles). The analysis of the atomic composition of the detected particles showed a high prevalence of non-fibrous silicates (67/109 particles; $61.4 \%)$ and particles of heavy elements (38/109 particles; $34 \cdot 9 \%$ ). One case contained 27 inorganic particles in the area studied, and one of these particles was the only asbestos fibre found in the normal group (1/109 particles; $0.9 \%)$. This patient, together with all others in the normal group, had no relevant inhalatory antecedents (table 3 ).

\section{Discussion}

Our results provide evidence that an examination using optical microscopy and polarised light overdiagnoses IPF. We found $2 / 24$ cases with a previous diagnosis of IPF (8.3\%) that contained innumerable asbestos fibres in the area studied, with no asbestos

Table 3 Inorganic particles in normal lung types

\begin{tabular}{|c|c|c|}
\hline Patient & No of Particles & Type \\
\hline 26 & 7 & $\begin{array}{l}\text { Silicate (4) } \\
\mathrm{Fe}(3)\end{array}$ \\
\hline 27 & 6 & $\begin{array}{l}\text { Silicate (3) } \\
\mathrm{Fe} \mathrm{(3)}\end{array}$ \\
\hline 28 & 6 & $\begin{array}{l}\text { Silicate (1) } \\
\text { Silica (2) } \\
\mathrm{Fe} \mathrm{(2)} \\
\mathrm{ZnCu}(1)\end{array}$ \\
\hline 29 & 5 & $\begin{array}{l}\text { Silicate (4) } \\
\text { Silica (1) }\end{array}$ \\
\hline 30 & 5 & $\begin{array}{l}\text { Silicate (4) } \\
\mathrm{ZnCu} \mathrm{(1)}\end{array}$ \\
\hline 31 & 27 & $\begin{array}{l}\text { Silicate (11) } \\
\text { Asbestos (1) } \\
\mathrm{Pb}(15)\end{array}$ \\
\hline 32 & 3 & $\begin{array}{l}\text { Silicate (1) } \\
\mathrm{Al}(1) \\
\mathrm{Ag}(1)\end{array}$ \\
\hline 33 & 0 & - \\
\hline 34 & 8 & Silicate (8) \\
\hline 35 & 0 & - \\
\hline 36 & 4 & Silicate (4) \\
\hline 37 & 4 & Silicate (4) \\
\hline 38 & 5 & $\begin{array}{l}\text { Silicate (2) } \\
\mathrm{Fe}(3)\end{array}$ \\
\hline 39 & 3 & Silicate (3) \\
\hline 40 & 2 & Silicate (2) \\
\hline 41 & 0 & - \\
\hline 42 & 0 & - \\
\hline 43 & 5 & Silicate (5) \\
\hline 44 & 9 & $\begin{array}{l}\text { Silicate (7) } \\
\mathrm{Fe}(2)\end{array}$ \\
\hline 45 & 1 & Silicate (1) \\
\hline 46 & 7 & $\begin{array}{l}\text { Silicate (3) } \\
\mathrm{Al}(1) \\
\mathrm{Cu}(1) \\
\mathrm{Fe}(2)\end{array}$ \\
\hline 47 & 1 & $\mathrm{Fe}(1)$ \\
\hline 48 & 0 & - \\
\hline 49 & 1 & $\mathrm{Fe}(1)$ \\
\hline 50 & - & - \\
\hline
\end{tabular}


bodies. The final diagnosis for these cases must be asbestosis. ${ }^{10}$

It has been previously suggested that IPF, or more probably a subgroup of it, could in fact be pneumoconiosis not diagnosed by standard techniques, ${ }^{511-18}$ Until now this opinion has been poorly founded on original work with no control group. ${ }^{15}$ Most of the asbestos fibres are below the $0.2 \mu \mathrm{m}$ resolution of the optical microscope,${ }^{19}$ and will not be detected with a conventional examination. ${ }^{20}$ Asbestos bodies, however, are usually easily identified and allow the diagnosis of asbestosis (two or more asbestos bodies in a pulmonary fibrosis lung sample). ${ }^{21}$ There exists a relation between the number of asbestos bodies and the number of asbestos fibres in the lung, ${ }^{22}{ }^{23}$ but this relation is extremely variable. ${ }^{24-26}$ It is clear, however, that the lung content of asbestos fibres is always much higher than the lung content of asbestos bodies. ${ }^{24}{ }^{27}$ This situation allows that a patient with asbestosis, sampled in an area that does not show asbestos bodies, was erroneously diagnosed as having IPF after examination with optical microscopy and polarised light. ${ }^{2829} \mathrm{~A}$ more sensitive analysis will correct the diagnosis.

The SEM examination of a lung sample in cases of IPF combined with the determination of the atomic composition of the inorganic particles using EDXA is easier than a mineralogical analysis using destructive techniques ${ }^{30-32}$ and can be used as a complementary study in cases of a questionable diagnosis. Moreover, surface SEM examination offers the advantage that it can be used on samples obtained by lung biopsy that cannot be used for mineralogical analysis because there is not enough tissue available (such as our IPF lung samples).

Inorganic particles in normal lungs have not been previously studied in the western Mediterranean population. Our study shows that the particles found are mainly non-fibrous silicates $(61.4 \%)$, and, rarely, silica $(2 \cdot 75 \%)$. We also found a high proportion of particles of heavy elements $(34.9 \%)$.

It is well known that particles of silica and nonfibrous silicates can be found in normal lungs. ${ }^{33}$ Berry et al studied 40 normal lungs and found $\mathrm{Fe}, \mathrm{Ti}$, and Al silicates with amorphous structure. ${ }^{11}$ Brambrilla $e t$ al, examining the lungs of animals of San Diego zoo, found $95 \%$ of silicates, $5 \%$ of silica, and $5 \%$ of particles of heavy elements. The silicates were identified by $x$ ray diffraction as mica. ${ }^{34}$

Our results allow us to conclude that standard techniques overdiagnose IPF. The use of more sensitive, non-destructive techniques such as SEM and EDXA in diagnosis of IPF could show that some of the lung samples with a previous diagnosis of IPF are really asbestosis.

The study was supported by Institut d'Estudis Catalans, SEPAR and FiSss 90/0431.
Requests for reprints to: Dr Eduard Monsó, Servei de Pneumologia, Hospital Germans Trias i Pujol, Ap correus 72, 08916 Badalona, Catalonia, Spain.

1 DeVuyst $P$, Jedwab J. L'analyse minéralogique en pathologie respiratorie. Rev Med Brux 1981;2:115-9.

2 DeVuyst P, Dumortier P, Rickaert F, Van de Weyer R, Lenclud $\mathrm{C}$, Yernault JC. Occupational lung fibrosis in an aluminium polisher. Eur J Respir Dis 1986;68:131-40.

3 DeVuyst $\mathrm{P}$, Van de Weyer R, DeCoster A, et al. Dental technician's pneumoconiosis. A report of two cases. Am Rev Respir Dis 1986;133:316-20.

4 Morgenroth K, Blaschke R, Schlake W. Energy dispersive X ray analysis of semi-thin section in the scanning transmission. Beiträge zur Pathologie 1973;150:406-11.

5 Monsó E, Tura JM, Marsal M, Morell F, Pujadas J, Morera J. Mineralogical microanalysis of idiopathic pulmonary fibrosis. Arch Environ Health 1990;45:185-9.

6 Ghadially FN. The technique and scope of electron-probe $x$-ray analysis in pathology. Pathology 1979;11:95-110.

7 Davis JMG, Gylseth B, Morgan A. Assessment of mineral fibres from human lung tissue. Thorax 1986;41:167-75.

8 Mossman BT, Gee JBL. Asbestos-related diseases. New Engl J Med 1989;320:1721-30.

9 Murphy RL, Becklake MR, Brooks SM, et al. The diagnosis of non-malignant diseases related to asbestos. Am Rev Respir Dis 1986;134:363-8.

10 Churg A. Nonneoplastic diseases caused by asbestos. In: Churg A, Green FHY, eds. Pathology of occupational lung disease. New York: Igaku-Shoin, 1988:213-78.

11 Berry JP, Henoc P, Galle P, Pariente R. Pulmonary mineral dust. A study of ninety patients by electron microscopy, electron microanalysis and electron microdiffraction. Am J Pathol 1976;83:427-38.

12 Rüttner JR, Spycher MA, Sticher H. The detection of etiologic agents in interstitial pulmonary fibrosis. Hum Pathol 1973;4:497-512

13 Miller A, Langer AM, Teirstein AS, Selikoff IJ. Nonspecific interstitial pulmonary fibrosis. Association with asbestos fibers detected by electron microscopy. $N$ Engl J Med 1975;292:91-3.

14 Pariente R, Berry JP, Galle P, Cayrol E, Brouet G. A study of pulmonary dust deposits using the electron microscope in conjunction with the electron sound analyser. Thorax 1972;27:80-2.

15 Abraham JL, Hertzberg MA. Inorganic particulates associated with desquamative interstitial pneumonia. Chest 1981;80: $67-70$.

16 Abraham JL, Spragg RG. Documentation of environmental exposure using open biopsy, transbronchial biopsy and bronchopulmonary lavage in giant cell interstitial pneumonia (GIP). Am Rev Respir Dis 1979;119:197.

17 Davison AG, Haslam PL, Corrin B, et al. Interstitial lung disease and asthma in hard metal workers: bronchoalveolar lavage, ultrastructural, and analytical findings and results of bronchial provocation tests. Thorax 1983;38:119-28.

18 Stettler LE, Groth DH, Mackay GR. Identification of stainless steel welding fume particulates in human lung and environmental samples using electron probe microanalysis. $\mathrm{Am}$ Ind Hyg Assoc $J$ 1977;38:76-86.

19 Churg A. Non asbestos pulmonary mineral fibers in the general population. Environ Res 1983;31:189-200.

20 Dodson RF, Hurst GA, Williams MG, Corn C, Greenberg SD. Comparison of light and electron microscopy for defining occupational asbestos exposure in transbronchial lung biopsies. Chest 1988;94:366-70.

21 Craighead J, Abraham J, Churg A, et al. Pathology standards for the diagnosis of asbestos related diseases. Arch Pathol Lab Med 1982;106:543-97.

22 Whitwell F, Scott J, Grimshaw M. Relationship between occupations and asbestos fibre content of the lungs in patients with pleural mesothelioma, lung cancer and other diseases. Thorax 1977;32:377-86.

23 Ashcroft T, Heppleston AG. The optical and electron microscopic determination of pulmonary asbestos fibre concentration, and its relation to the human pathological reaction. J Clin Pathol 1973;26:224-34.

24 Morgan A, Holmes A. Concentrations and dimensions of coated and uncoated asbestos fibres in the human lung. $\mathrm{Br} J$ Ind Med $1980 ; 37: 25-32$. 
25 Kobayashi $\mathrm{H}$, Watanabe $\mathrm{H}$, Zhang WM, Ohnishi Y. A quantitative and histological study of pulmonary effects of asbestos exposure in general autopsied lungs. Acta Pathol Jpn 1986;36:1781-91.

26 Case BW, Sebastien P. Environmental and occupational exposures to chrysotile asbestos: a comparative microanalitic study. Arch Environ Health 1987;42:185-91.

27 Pooley FD, Ranson DL. Comparison of the results of asbestos fibre dust counts in lung tissue obtained by analytical electron microscopy and light microscopy. J Clin Pathol 1986;39: 313-7.

28 Dodson RF, Williams Jr MG, O'Sullivan MF, Corn CJ, Greenberg SD, Hurst GA. A comparison of the ferruginous body and uncoated fiber content in the lungs of former asbestos workers. Am Rev Respir Dis 1985;132:143-7.

29 Churg A. The diagnosis of asbestosis. Hum Pathol 1989;20:97-9.

30 DeNee PB. Identification and analysis of particles in biological tissue using SEM and related techniques. In: O'Hare AMF, Johari O, Becker RP, eds. SEM/1976/III. SEM Inc. IL60666. Chicago: ITT Research Institute IL60666, 1976:461-8.

31 Vallyathan NV, Green FHY, Craighead JE. Recent advances in the study of mineral pneumoconiosis. Pathol Annu 1980;15: $77-104$.

32 Henderson WJ, Melville-Jones C, Wilson DW, Griffiths K. Oxygen incineration and electron microscope $x$-ray microanalysis of mineral particles in biological tissues. $J$ Histochem Cytochem 1978;26:1087-93.

33 Ziskind M, Jones RN, Weill H. Silicosis. Am Rev Respir Dis 1976;113:643-65.

34 Brambilla C, Abraham J, Brambilla E, Bemrschke K, Bloor C. Comparative pathology of silicate pneumoconiosis. $\mathrm{Am} \mathrm{J}$ Pathol 1979;96:149-70.

Accepted 12 November 1990

\section{Destruction of manuscripts}

From 1 July 1985 articles submitted for publication will not be returned. Authors whose papers are rejected will be advised of the decision and the manuscripts will be kept under security for three months to deal with any inquiries and then destroyed. 